\title{
Variation in Growth, Yield and Quality of Happy Seeder Sown Wheat with Different Planting Patterns and Times of Nitrogen Application
}

\author{
Raminder Kaur Hundal*, J.S. Kang and Avtar Singh \\ Department of Agronomy, Punjab Agricultural University, Ludhiana-141004, India \\ *Corresponding author
}

\author{
A B S T R A C T
}

Field experiment was conducted to determine the effects of planting patterns and time of nitrogen $(\mathrm{N})$ application on growth, yield and quality of wheat in a split plot design during Rabi 2011-12 and 2012-13. The treatments consisted of three planting pattern $\left(\mathrm{M}_{1}-3\right.$ rows

Keywords

CGR, LAD,

Quality, Skip

Row Planting,

Time of $\mathrm{N}$

application,

Wheat, Yield.

Article Info

Accepted:

17 June 2017

Available Online:

10 August 2017 at $20 \mathrm{~cm}$ inter-row spacing and $40 \mathrm{~cm}$ space between two sets of rows, $\mathrm{M}_{2}-2$ rows at $20 \mathrm{~cm}$ inter-row spacing and $40 \mathrm{~cm}$ space between two sets of rows, $\mathrm{M}_{3}-\mathrm{Normal}$ sowing at $20 \mathrm{~cm}$ row spacing) in the main plots and six $N$ scheduling $\left(\mathrm{T}_{1}\right.$-Control:; $\mathrm{T}_{2^{-}} 1 / 2$ dose of recommended $\mathrm{N}$ basal+ $1 / 2$ dose of recommended $\mathrm{N}$ with $1^{\text {st }}$ irrigation; $\mathrm{T}_{3}-\mathrm{No}$ basal+ $1 / 2$ dose of recommended $\mathrm{N}$ with $1^{\text {st }}$ irrigation $+1 / 2$ dose of recommended $\mathrm{N}$ with $2^{\text {nd }}$ irrigation ; $\mathrm{T}_{4^{-}} 3 / 4$ dose of recommended $\mathrm{N}$ basal+ $1 / 4$ dose of recommended $\mathrm{N}$ with $1^{\text {st }}$ irrigation; $\mathrm{T}_{5^{-}} 1 / 4$ dose of recommended $\mathrm{N}$ basal+ $3 / 4$ dose of recommended $\mathrm{N}$ with $1^{\text {st }}$ irrigation; $T_{6^{-}} 1 / 4$ dose of recommended $\mathrm{N}$ basal+ $1 / 4$ dose of recommended $\mathrm{N}$ with $1^{\text {st }}$ irrigation $+1 / 2$ dose of recommended $\mathrm{N}$ with $2^{\text {nd }}$ irrigation) in sub- plots. The treatments were replicated three times. Results revealed that M1 and M3 methods produced nonsignificant $(p<0.05)$ grain yield i.e. 54.2, 51.4 and 52.1, $49.8 \mathrm{q} / \mathrm{ha}$, respectively and significantly lower than $\mathrm{M}_{2}$ during both the years of study. Higher values of crop growth rate (CGR) and leaf area duration (LAD) at 90 days after sowing (DAS) were observed in $\mathrm{M}_{1}$ as compared to $\mathrm{M}_{2}$ and $\mathrm{M}_{3}$. Split applications of nitrogen significantly affect the yield and yield contribution characters. When nitrogen applied as $1 / 4^{\text {th }}$ as basal $+1 / 4^{\text {th }}$ after $1^{\text {st }}$ irrigation $+1 / 2$ after $2^{\text {nd }}$ irrigation $\left(\mathrm{T}_{6}\right)$, it had $37.2,4.8,5.3,8.7,3.4 \%$ and $34.8,5.1,6.7$, $10.7,7.1 \%$ higher grain yield than $\mathrm{T}_{1}, \mathrm{~T} 2, \mathrm{~T} 3, \mathrm{~T} 4$ and $\mathrm{T} 5$ treatments during 2011-12 and 2012-13, respectively. Quality parameters of wheat were also better under T6 treatment.

\section{Introduction}

In the Indo-Gangetic Plain of north-west India, rice-wheat cropping system (RWCS) is the most dominant and profitable system. In Punjab, rice is grown more than 2.6 million hectares and most of the rice is mechanically harvested, leaving heavy loads (more $6 \mathrm{t} / \mathrm{ha}$ ) of anchored straw and loose straw in windrows. Due to climate change timeframe between the harvesting of succeeding rice crop and sowing the proceeding wheat crop became very short so the farmers have managed the heavy straw loads through the practice of burning. Conservation agriculture plays a pivotal role for residue management. This system deliberately reduce primary intercrop tillage operations such as ploughing, disking, ripping and chiselling, and either preserve $30 \%$ or more residue cover or reduce the total number of tillage passes by $40 \%$. Crop residues reduce the evaporation of water from soil by shading, causing a lower surface soil temperature and reducing wind effects. 
Keeping in view the benefits of conservation agriculture, the Australian Centre for International Agricultural Research (ACIAR) has been supporting the development of sustainable alternatives to straw burning principally through the development of a direct drilling machine known as the Happy Seeder. The Happy Seeder thus combines stubble mulching and seed and fertilizer drilling in a single pass (Sidhu, et al., 2008).

When sowing crops in rows, the space between the rows must be chosen to maximise both yield and profit. In an ideal world, the perfect row spacing is where the spacing between the plants along the row equals the distance between the rows (Fischer and Miles, 1973). Row spacing requirements of wheat depend on architecture and growth pattern of the varieties. For higher yield, higher proportion of incident radiation at the soil surface must be intercepted by the crop canopy (Eberbach and Pala, 2005). Skip planting geometry with pairs of row allow more light penetration inside plant canopy, while in solid geometry the field is more populated and there is less light penetration inside plant canopy. Skip or wider planting geometry makes application of herbicides, other fertilizer and intercultural practices for weed control easier as compared to solid planting geometry. Narrow row spacing results in higher leaf photosynthesis and suppresses weed growth due to smothering effect compared with wider row spacing (Dwyer, et al., 1991). Stubble (standing or surface crop residues) retention is a common practice in conservation agriculture due to many benefits such as moisture and nutrient conservation, soil erosion control, and improved soil health and structure. Increasing type spacing to sow crops in wider rows allows greater amount and length of crop residue to pass through them, which minimises the blockage commonly encountered in narrow row spacing (Slattery,
1998). Wider rows also facilitate the use of row clearing attachments, which help to maintain uniform sowing depth, resulting in good and uniform plant emergence.

Among various agronomic manipulations, application of nitrogen is one of the important factors, which influences the grain yield and quality of wheat. The efficiency of the $\mathrm{N}$ applied in satisfying the $\mathrm{N}$ demand of the crop depends on the type of fertilizer, timing of application, seasonal trends (Huggins and Pan, 1993; Borghi, 2000 and Blankenau, et al., 2002). Crop response to $\mathrm{N}$ fertilizer is also influenced by soil type, crop sequence and the supply of residual and mineralized $\mathrm{N}$. Time of application of nitrogen fertilizer in residue retaining fields is different than the normal sown. About $75 \%$ of recommended calories intake from cereals, emphasize the need for enhancing its protein content. Though the protein content depends mainly on genetic characters, it may be possible to certain extent by the fertilizer management of crop (Krishankumari, et al., 2000). Kaur, et al., (2010) reported from Hisar that the quality of wheat grain in terms of increased protein fractions like albumin, globulin, prolamin and glutenin increased significantly with split application of $\mathrm{N}$.

In this paper, we examined combinations of skip row planting and $\mathrm{N}$-fertilizer application time in happy seeder sown wheat crop with the view to optimize grain production as well as trying to establish an overarching management protocol that will achieve good quality targets. This study will be useful to accelerate the adoption of happy seeder for sowing of wheat in in-situ rice straw in the rice-wheat growing area of the world.

\section{Materials and Methods}

A replicated field experiment to investigate the effects of planting patterns and $\mathrm{N}$ 
application time on growth, yield and quality of happy seeder sown wheat was conducted for two seasons of 2011-12 and 2012-13 at the Punjab Agricultural University (PAU) farm at Ludhiana $\left(30 \circ 56^{\prime} \mathrm{N}, 75^{\circ} 52^{\prime} \mathrm{E}, 247 \mathrm{~m}\right.$ ASL), Punjab, India. The region is characterized by a sub-tropical and semi-arid climate with a hot dry summer (March-June), wet monsoon season (late June-mid September) and a cool, dry winter (OctoberFebruary). Average annual rainfall is $734 \mathrm{~mm}$ (constituting $44 \%$ of pan evaporation) of which about $80 \%$ is received during the monsoon. The top soil of the experimental site was clay loam over lying silt clay, with an abrupt change to sandy loam at about $90 \mathrm{~cm}$. Bulk density was $1.50 \mathrm{gcm}^{-3}$ in the topsoil. The soil was slightly alkaline $(\mathrm{pH} 7.8-8.3)$ with low soil organic $\mathrm{C}$ content, which decreased from $\left(3.7 \mathrm{~g} \mathrm{C} \mathrm{kg}^{-1}\right.$ at $0-15 \mathrm{~cm}$ to $2.2 \mathrm{~g} \mathrm{C} \mathrm{kg}^{-1}$ at $15-30 \mathrm{~cm}$ ).

The experimental site had been under a R-W system for more than 5 years. The experiment was laid out in a split plot design with three planting pattern (M1-3 rows at $20 \mathrm{~cm}$ interrow spacing and $40 \mathrm{~cm}$ space between two sets of rows, M2-2 rows at $20 \mathrm{~cm}$ inter-row spacing and $40 \mathrm{~cm}$ space between two sets of rows, M3-Normal sowing at $20 \mathrm{~cm}$ row spacing) in the main plots and six $\mathrm{N}$ scheduling (T1Control:; T2- 1/2 dose of recommended $\mathrm{N}$ basal+ $1 / 2$ dose of recommended $\mathrm{N}$ with $1^{\text {st }}$ irrigation; T3- No basal+ $1 / 2$ dose of recommended $\mathrm{N}$ with $1^{\text {st }}$ irrigation $+1 / 2$ dose of recommended $\mathrm{N}$ with $2^{\text {nd }}$ irrigation ; T4$3 / 4$ dose of recommended $\mathrm{N}$ basal+ $1 / 4$ dose of recommended $\mathrm{N}$ with $1^{\text {st }}$ irrigation; T5- 1/4 dose of recommended $\mathrm{N}$ basal+ 3/4 dose of recommended $\mathrm{N}$ with $1^{\text {st }}$ irrigation; T6- 1/4 dose of recommended $\mathrm{N}$ basal+ $1 / 4$ dose of recommended $\mathrm{N}$ with $1^{\text {st }}$ irrigation $+1 / 2$ dose of recommended $\mathrm{N}$ with $2^{\text {nd }}$ irrigation) in subplots. The treatments were replicated three times. Data were subjected to analysis of variance (ANOVA) using the general linear model (GLM) procedures of the Statistical Analysis System followed by Tukey's Test at $\mathrm{P}<0.05$.

\section{Results and Discussion}

The data on maximum CGR recorded at 6090 days after sowing as it is the grand growth period of the crop (Fig1 and Fig.2). Highest dry matter per day accumulated in M3, which was at par with M1, and significantly higher from M2 in both years. The all methods with T5 nitrogen treatment combination had higher CGR rate as it received higher dose of $\mathrm{N}$ fertilizer after first irrigation, resulted in higher dry matter production. When nitrogen applied as per T4 (3/4 at sowing+1/4 with first irrigation) resulted in lower CGR rate under all planting pattern. LAD was more in M1 followed by M3 and M2. In nitrogen treatments, all treatments except control were at par for LAD at 90 DAS. Wheat grain yield was significantly affected by the skip row planting methods and time of $\mathrm{N}$-applications. M1 and M3 methods produced nonsignificant $(p<0.05)$ grain yield i.e. 54.2, 51.4 and 52.1, $49.8 \mathrm{q} / \mathrm{ha}$, respectively during 201011 and 2011-12. M1 and M3 methods significantly differ from M2 during both the years of study. This might be associated with the higher number of productive tillers bearing more number of bold grains (Table1). Higher values of spike length, No. of grains per spike,1000-grain weight and effective tillers in M1 and M3 over M2 helped to attained higher grain yield during both the years. Grain yield during second year decreased due to heavy rainfall during the month of February and then sudden rise in temperature. Similarly, it was observed that the spilt application of nitrogen influences the yield and yield contributing characters over the two years as a whole. The best results were obtained when nitrogen was applied $1 / 4$ at the time of sowing, $1 / 4$ dose with $1^{\text {st }}$ irrigation (i.e. CRI stage) and $1 / 2$ dose with $2^{\text {nd }}$ 
irrigation (i.e. initiation of stem elongation stage).The results showed that the highest grain yield of 56.8 and $54.08 \mathrm{q} / \mathrm{ha}$ in the above said treatment during 2010-11 and 2011-12, respectively. Whilst, the lower grain yield of $35.4 \mathrm{q} / \mathrm{ha}$ and $35.9 \mathrm{q} / \mathrm{ha}$ was received under the control treatment. Split application also contributed to produce more effective tillers with bold kernel size (Table 2). The data on quality parameters was given in table 2. The grain appearance was given a score on a scale of 0 to 10. During first year M1 (5.71), and M2 (5.74) were at par. M2 gave significantly good appearance over M3 (5.52). During second year skip row techniques showed non-significant grain appearance but M2 recorded numerical higher values (5.57) of grain appearance. Among nitrogen time application treatments, the results were significantly differed over control. Grain appearance at T6 was significantly higher on control, and was statistically on par with T2, T3, T4 and T5 treatments. During first year planting methods had non-significant effect but in the second year, M1 (11.16) had significant higher grain hardness over M2 (11.52) and M3 (11.34). The nitrogen application time treatment T6 had significantly highest grain hardness (12.16, 11.35 during $1^{\text {st }}$ and $2^{\text {nd }}$ year) over control, and at par with other nitrogen application time treatments.

Methods had non-significant effect on hectolitre weight. However, nitrogen application time treatment T6 had significantly higher hectolitre weight as compared to control, and at par with all other nitrogen application time treatments. Sedimentation value was unaffected with planting methods and $\mathrm{N}$ application rates. The method M1 recorded the highest protein content followed by M2, and M3. All the nitrogen application time treatments significantly recorded higher protein content than $\mathrm{T} 1, \mathrm{~T} 2$ and $\mathrm{T} 3$ treatments. The nitrogen supply for a longer period i.e. up to stem elongation (T6) recorded significantly highest protein content in grain as compared to all other nitrogen treatments.

The efficient use of available sources resulted in higher LAI under M1 over M2 and M3 planting pattern as there was inefficient utility of available sources in M2 planting pattern. Leaves are units of the assimilatory system of plants, therefore higher LAI under M1 method due to border effect resulted in more accretion of photosynthates and ultimately higher CGR, during both years of the study in almost all planting pattern and nitrogen application treatments over control. The greater LAD noted $\mathrm{M} 1$ and M2 were attributed to higher LAI; because LAD was directly computed from LAI (Figures 1 and 2). The PAR interception had good correlation with LAI at 90 DAS. There was more PAR interception as LAI increased. With more dry matter accumulation, as evident from the higher CGR, in M1 and M3 during both years of the study and $30-\mathrm{cm}$ spacing during the first year of the study exhibited higher biological yield than M2. Earlier, Ayaz, et al., (1999) and Kakar, et al., (2001) reported similar findings in wheat.

Adoption of optimal row spacing plays a crucial role in elevating the productivity of cereal crops; plants growing in rows that are too wide may not efficiently utilize the natural available resources such as light, water and nutrients; whereas growth in rows that are too narrow may result in severe inter-row competition (Ali, et al., 1999). Therefore, substantial increases in yield-related traits under M1 may be attributed to the efficient utilization of light, water and nutrients, etc. Row spacing is a prominent factor that directly influences wheat yield. Likewise, row spacing might change plant architecture, photosynthetic competence of leaves and dry matter portioning of field crops. 
Table.1 Effect of skip row planting and time of Nitrogen application on the yield contributing characters and yield of wheat

\begin{tabular}{|c|c|c|c|c|c|c|c|c|c|c|}
\hline \multirow{2}{*}{ Treatment } & \multicolumn{2}{|c|}{ Spike length $(\mathrm{cm})$} & \multicolumn{2}{|c|}{ No. of grains per spike } & \multicolumn{2}{|c|}{ 1000-grain weight $(\mathrm{g})$} & \multicolumn{2}{|c|}{ Effective tillers $\left(\mathrm{m}^{2}\right)$} & \multicolumn{2}{|c|}{ Grain yield (q/ha) } \\
\hline & $2010-11$ & $2011-12$ & $2010-11$ & $2011-12$ & $2010-11$ & $2011-12$ & $2010-11$ & $2011-12$ & $2010-11$ & $2011-12$ \\
\hline \multicolumn{11}{|c|}{ SKIP ROW PLANTING PATTERN } \\
\hline M1 & $10.7 \mathrm{a}$ & $10.4 \mathrm{a}$ & $45.8 \mathrm{a}$ & $45.3 \mathrm{a}$ & $34.74 a$ & $34.77 \mathrm{a}$ & $341 \mathrm{a}$ & $334 a$ & $54.2 \mathrm{a}$ & $52.1 \mathrm{a}$ \\
\hline M2 & $11.3 \mathrm{a}$ & $10.3 \mathrm{a}$ & $45.5 \mathrm{a}$ & $44.3 \mathrm{a}$ & $34.93 \mathrm{a}$ & $34.62 \mathrm{ab}$ & $314 b$ & $309 b$ & $46.9 \mathrm{~b}$ & $45.6 b$ \\
\hline M3 & $10.6 \mathrm{a}$ & $10.3 \mathrm{a}$ & $45.7 \mathrm{a}$ & $44.7 \mathrm{a}$ & $34.40 \mathrm{a}$ & $33.78 b$ & $337 \mathrm{a}$ & $329 a$ & $51.4 \mathrm{a}$ & $49.8 \mathrm{a}$ \\
\hline \multicolumn{11}{|c|}{ NITROGEN APPLICATION TIME } \\
\hline $\mathrm{T} 1$ & $9.7 \mathrm{~b}$ & $9.2 b$ & $41.4 \mathrm{~b}$ & $40.7 \mathrm{~b}$ & $32.94 b$ & $31.70 \mathrm{~b}$ & $281 b$ & $267 b$ & $35.4 \mathrm{~b}$ & $35.9 \mathrm{~b}$ \\
\hline $\mathrm{T} 2$ & $11.1 \mathrm{a}$ & $10.5 \mathrm{ab}$ & $47.8 \mathrm{a}$ & $45.6 \mathrm{a}$ & $35.23 \mathrm{ab}$ & $35.54 \mathrm{a}$ & $322 \mathrm{ab}$ & $315 \mathrm{ab}$ & $53.7 \mathrm{ab}$ & $52.3 \mathrm{a}$ \\
\hline T3 & $11.3 \mathrm{a}$ & $10.8 \mathrm{a}$ & $46.5 \mathrm{ab}$ & $46.1 \mathrm{a}$ & $34.93 \mathrm{ab}$ & $35.04 \mathrm{ab}$ & $340 \mathrm{a}$ & $322 \mathrm{ab}$ & $53.4 \mathrm{ab}$ & $51.4 \mathrm{ab}$ \\
\hline $\mathrm{T} 4$ & $10.8 \mathrm{a}$ & $10.2 \mathrm{ab}$ & $43.5 \mathrm{ab}$ & $42.6 \mathrm{ab}$ & $34.07 \mathrm{ab}$ & $33.92 \mathrm{ab}$ & $330 \mathrm{ab}$ & $342 \mathrm{a}$ & $51.5 \mathrm{ab}$ & $49.2 \mathrm{ab}$ \\
\hline T5 & $11.2 \mathrm{a}$ & $10.6 \mathrm{ab}$ & $47.7 \mathrm{a}$ & $46.8 \mathrm{a}$ & $35.41 \mathrm{a}$ & $34.40 \mathrm{ab}$ & $339 a$ & $332 \mathrm{a}$ & $54.5 \mathrm{ab}$ & $51.2 \mathrm{ab}$ \\
\hline T6 & $11.2 \mathrm{a}$ & $10.7 \mathrm{a}$ & $47.5 \mathrm{a}$ & $47.2 \mathrm{a}$ & $35.55 a$ & $35.72 \mathrm{a}$ & $373 a$ & $368 \mathrm{a}$ & $56.4 \mathrm{a}$ & $55.1 \mathrm{a}$ \\
\hline Interaction effects & NS & NS & NS & NS & NS & NS & NS & NS & NS & NS \\
\hline
\end{tabular}

Means with the same letter are non-significant at 5 per cent level of significance.

Table.2 Wheat quality as influenced by the skip row planting and time of nitrogen application in happy seeder sown wheat

\begin{tabular}{|c|c|c|c|c|c|c|c|c|c|c|}
\hline \multirow[t]{2}{*}{ Treatments } & \multicolumn{2}{|c|}{ Grain appearance } & \multicolumn{2}{|c|}{ Grain hardiness } & \multicolumn{2}{|c|}{ Test weight } & \multicolumn{2}{|c|}{ Protein value } & \multicolumn{2}{|c|}{ Sedimentation value } \\
\hline & $1^{\text {st }} \mathrm{yr}$ & $2^{\text {nd }} y r$ & $1^{\text {st }} \mathrm{yr}$ & $2^{\text {nd }} \mathrm{yr}$ & $1^{\text {st }} \mathrm{yr}$ & $2^{\text {nd }} y r$ & $1^{\mathrm{st}} \mathrm{yr}$ & $2^{\text {nd }} y r$ & $1^{\text {st }} \mathrm{yr}$ & $2^{\text {nd }} y r$ \\
\hline \multicolumn{11}{|c|}{ Skip row planting pattern } \\
\hline M1 & $5.71 \mathrm{ab}$ & $5.54 \mathrm{a}$ & $11.95 \mathrm{a}$ & $11.16 \mathrm{a}$ & $76.24 \mathrm{a}$ & $74.62 \mathrm{a}$ & $11.25 \mathrm{a}$ & $10.98 \mathrm{a}$ & $54 a$ & $55 \mathrm{a}$ \\
\hline M2 & $5.74 a$ & $5.57 \mathrm{a}$ & $11.52 \mathrm{a}$ & $10.73 b$ & $75.92 \mathrm{a}$ & $74.74 \mathrm{a}$ & $10.97 \mathrm{ab}$ & $10.76 \mathrm{ab}$ & $60 a$ & $60 a$ \\
\hline M3 & $5.52 b$ & $5.52 \mathrm{a}$ & 11.34 & $10.48 \mathrm{~b}$ & $76.01 \mathrm{a}$ & $74.69 \mathrm{a}$ & $10.86 b$ & $10.63 b$ & $58 \mathrm{a}$ & $58 \mathrm{a}$ \\
\hline \multicolumn{11}{|c|}{ Nitrogen application time } \\
\hline T1 & $5.37 \mathrm{~b}$ & $5.39 \mathrm{~b}$ & $11.06 \mathrm{~b}$ & $10.25 \mathrm{c}$ & $72.43 b$ & $71.26 \mathrm{~b}$ & $9.55 \mathrm{c}$ & $9.36 \mathrm{c}$ & $58 \mathrm{a}$ & $58 \mathrm{a}$ \\
\hline $\mathrm{T} 2$ & $5.64 \mathrm{ab}$ & $5.53 \mathrm{ab}$ & $11.79 \mathrm{ab}$ & $10.98 \mathrm{ab}$ & 75.88ab & $74.93 \mathrm{ab}$ & $10.99 \mathrm{~b}$ & $10.81 \mathrm{~b}$ & $57 \mathrm{a}$ & $57 \mathrm{a}$ \\
\hline T3 & $5.72 \mathrm{ab}$ & $5.58 \mathrm{a}$ & $11.61 \mathrm{ab}$ & $10.79 \mathrm{ab}$ & 76.68ab & $75.17 \mathrm{ab}$ & $11.25 \mathrm{~b}$ & $11.07 \mathrm{ab}$ & $57 \mathrm{a}$ & $57 \mathrm{a}$ \\
\hline $\mathrm{T} 4$ & $5.69 \mathrm{ab}$ & $5.53 \mathrm{ab}$ & $11.21 \mathrm{~b}$ & $10.40 \mathrm{bc}$ & $77.18 \mathrm{a}$ & $74.42 \mathrm{ab}$ & $11.06 \mathrm{~b}$ & $10.88 \mathrm{~b}$ & $57 a$ & $57 a$ \\
\hline T5 & $5.77 \mathrm{a}$ & $5.63 \mathrm{a}$ & $11.79 \mathrm{ab}$ & $10.98 \mathrm{ab}$ & $76.68 \mathrm{ab}$ & $75.50 \mathrm{ab}$ & $11.46 \mathrm{ab}$ & $11.27 \mathrm{ab}$ & $61 \mathrm{a}$ & $61 \mathrm{a}$ \\
\hline T6 & $5.77 \mathrm{a}$ & $5.62 \mathrm{a}$ & $12.16 \mathrm{a}$ & $11.35 \mathrm{a}$ & $77.50 \mathrm{a}$ & $76.83 a$ & $11.85 \mathrm{a}$ & $11.34 \mathrm{a}$ & $56 a$ & $56 a$ \\
\hline Interaction effects & NS & NS & NS & NS & NS & NS & NS & NS & NS & $\mathrm{NS}$ \\
\hline
\end{tabular}

Means with the same letter are non-significant at 5 per cent level of significance. 
Fig.1 Crop growth rate under different treatment combinations during the year 2010-11

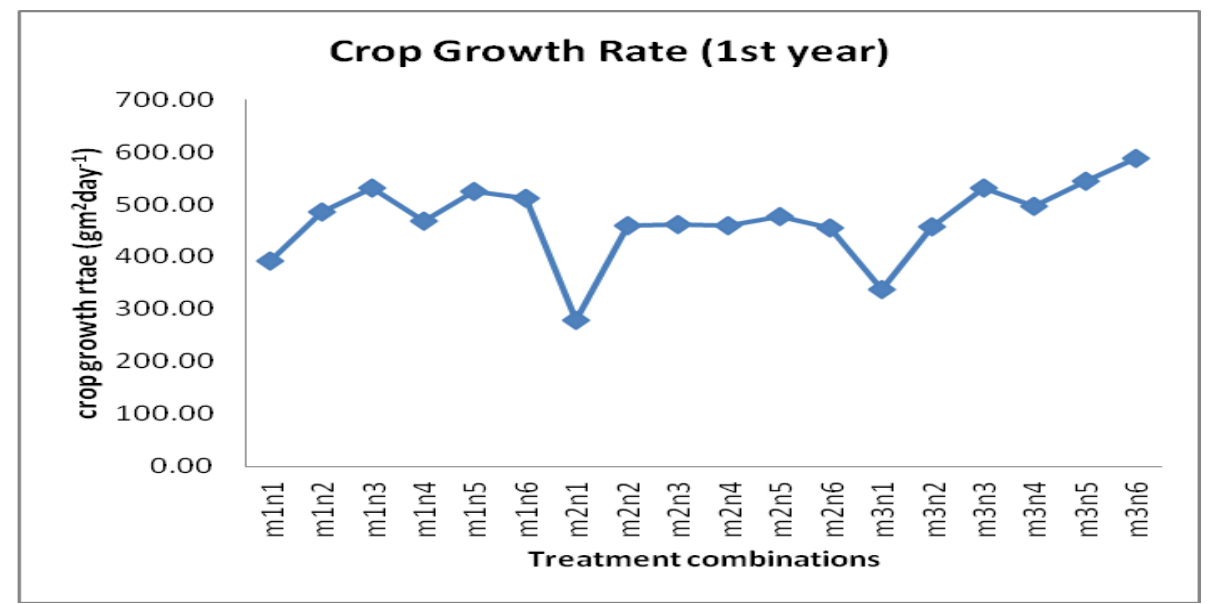

Fig. 2 Crop growth rate under different treatment combinations during the year 2011-12

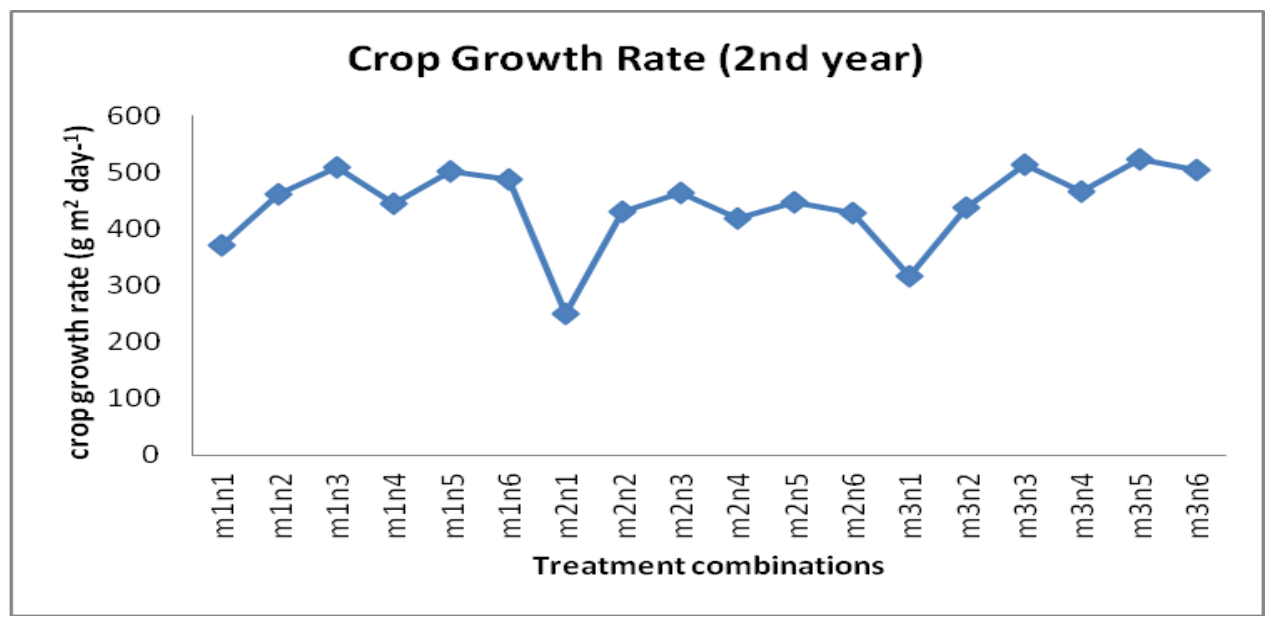

Fig.3 Leaf area duration under different treatment combination during the year 2010-11

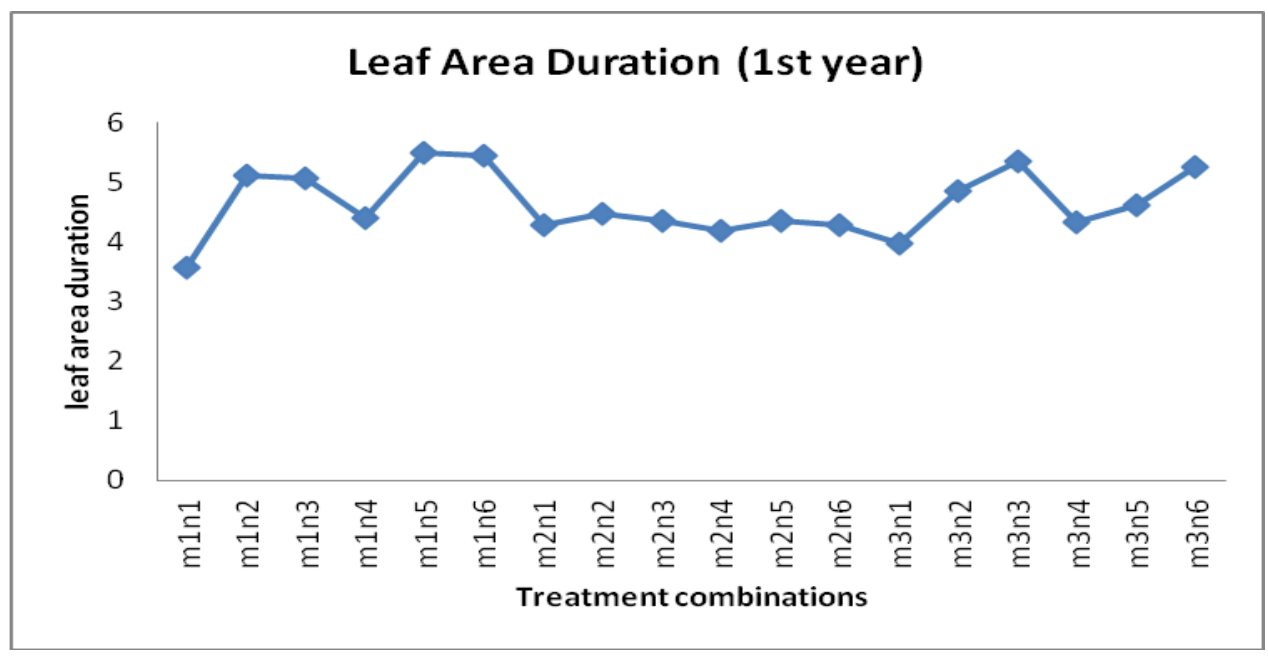


Fig.4 Leaf area duration under different treatment combination during the year 2011-12

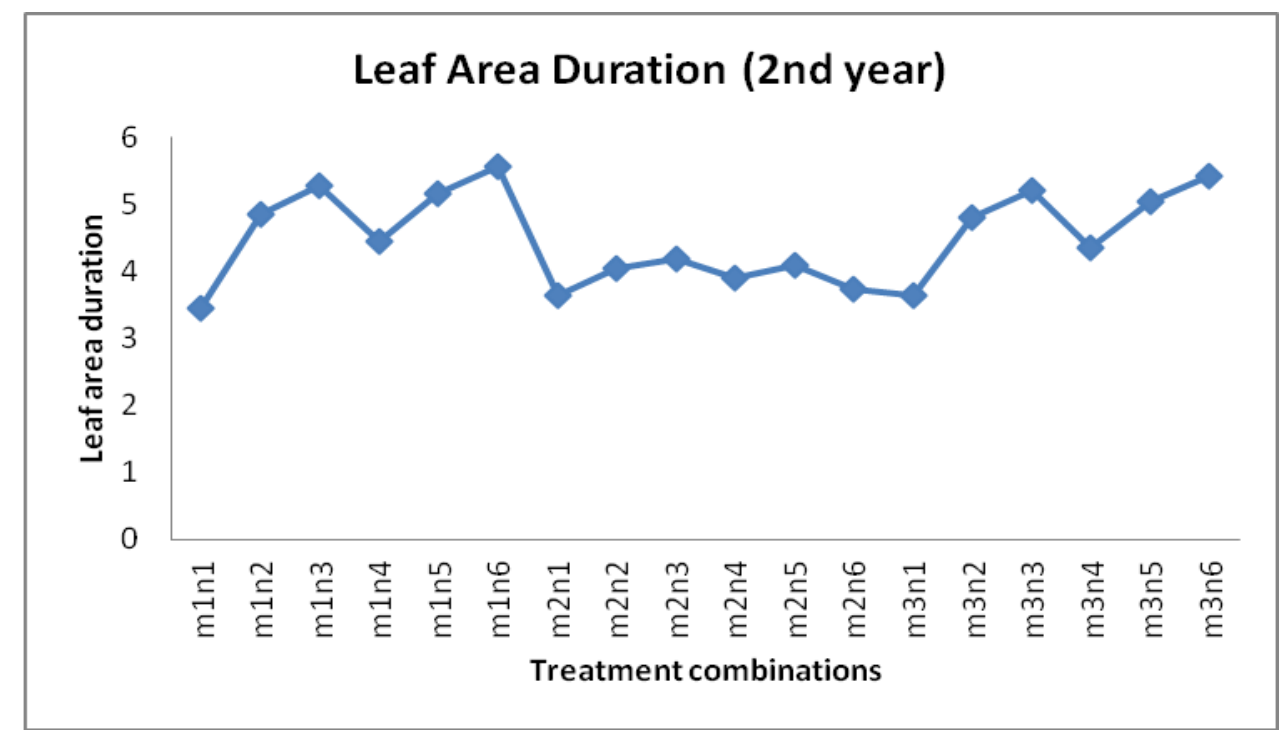

Ayaz et al., (1999) reported that row spacing had a significant effect on wheat yield, along with other yield-related traits. In M2 method the unsown area was 33\% and crop was not able to compensate this gap. But in M1 there was only $25 \%$ area was unsown, which was compensated with higher number of effective tillers and bolder seeds with higher 1000grain weight. Similar results were also reported by other researchers (Das and Yaduraju, 2011 and Weiner, et al., 2001).

Having 25\% of area unsown gave higher yield whereas the reverse was true for 33\% area unsown. Wheat plants are adapted to close growing conditions, and have high potential for tillering and canopy formation. They also show a considerable plasticity in growth. For these reasons, wheat plants should respond to missing row sowing.

The wheat crop was most competitive under the sowing system of $25 \%$ area unsown and least competitive with $33 \%$ area unsown. A slight change in the spatial uniformity and a small reduction in seed rate (by 25\%) with 25\% area unsown proved complementary, and resulted in better weed suppression. Probably, wheat plants could maintain density, in terms of total number of tillers, at optimal or near optimal level, through increased tillering (Table 1).

Lo'pez-Bellido, et al., (2005) also reported an increase in yield when $\mathrm{N}$ was applied in two splits specially at CRI and start of stem elongation stage. Salmanowicz et al., (2012) observed in Poland that grain hardness significantly increased with increasing nitrogen fertilization. The increasing of grain protein content is following increasing of sedimentation value, gluten content, grain hardness, and other technological quality parameters of flour, and bread. Singh and Agarwal (2005) and Kachroo and Razdan (2006) also confirmed that split application had higher hectolitre weight. Interaction effect of wheat varieties and nitrogen levels on grain hardness was found to be nonsignificant. The data pertaining to the protein content have been presented in table 2 revealed that split application of $\mathrm{N}$ fertilizer lead to higher protein content in grain. These results are in line with the findings of Jakhar, et al., (2005). Ellen and Spiertz (1980) have reported that a late nitrogen application 
during the boot stage increases grain number, harvest index, and grain yield as well as the protein concentration of grain. The potential for an increase in grain yield, and protein to occur through strategic nitrogen application has been demonstrated in other studies, both in rain-fed systems, and irrigated systems, throughout the world (Wuest and Cassman 1992) Garrido-Lestache et al., (2004) have also shown under rainfed Mediterranean conditions, with split applications of $\mathrm{N}$ fertiliser, an increased wheat grain protein outcome associated with improved bread baking quality. Interaction effect of wheat varieties and nitrogen levels on protein content was found to be non-significant.

The results of the investigation revealed that by using a technique of $25 \%$ area (M1) unsown better to obtain the higher grain yield than 33\% missing area sowing (M2) and normal sowing (M3). Sowing of wheat with this technique can save $25 \%$ seed, and get an average of $5.0 \%$ higher grain yield than normal sowing. However, the differences were significantly higher under M1 over the M2.Time of split nitrogen application influenced significantly on the performance of wheat crop. Highest grain yield and better quality parameters were achieved when nitrogen was applied in three splits (1/4 dose of recommended $\mathrm{N}$ basal+ $1 / 4$ dose of recommended $\mathrm{N}$ with $1^{\text {st }}$ irrigation $+1 / 2$ dose of recommended $\mathrm{N}$ with $2^{\text {nd }}$ irrigation.

\section{Acknowledgments}

The authors are thankful to the Department of Agronomy, Punjab Agricultural University, Ludhiana, Punjab, India for approving this research work and providing necessary facilities during the course of investigation.

\section{References}

Ali, L., Q. Mohy-ud-din, and M.Ali, 2003. Effect of different doses of nitrogen fertilizer on the yield of wheat. International. J. Agric. and Biol., 4: 438-39.

Ayaz, S., P. Shah, H.M. Sharif, and I. Ali, 1999. Yield, yield components and other important agronomic traits of wheat as affected by seed rate and planting geometry. Sarhad. J. Agr., 15:255-262.

Das, T. K. and N.T. Yaduraju, 2011. Effects of missing-row sowing supplemented with row spacing and nitrogen on weed competition and growth and yield of wheat. Crop and Pasture Science, 62(1) 48-57

Dwyer, L.M., M. Tollenaar, and D.W. Stewar,t 1991. Changes in plant density dependence of leaf photosynthesis of maize (Zea mays L.) hybrids, 1959 to 1988. Can. J. Plant. Sci., 71:1-11.

Eberbach, P. and M. Pala, 2005. Crop row spacing and its influence on the partitioning of evapotranspiration by winter-grown wheat in northern Syria. Plant Soil, 268:195-208.

Ellen, J. and H.J. Spiertz, 1980. Effects of rate and timing of nitrogen dressings on grain yield formation of winter wheat (Triticum aestivum L.). Fert. Res., 1, 177-190.

Fischer, R.A. and R.E. Miles, 1973. The role of spatial pattern in competition between crop plants and weeds. A theoretical analysis. Mathematical Biosciences 18, 335-350.

Garrido-Lestache, E., R.J. Lopez-Bellido, L. Lopez-Bellido, 2004. Effect of $\mathrm{N}$ rate, timing and splitting and $\mathrm{N}$ type on bread-making quality in hard red spring wheat under rainfed Mediterranean conditions. Field Crops Res. 85, 213236.

Jakhar, P., J. Singh, and R.K. Nanwal, 2005. Effect of planting methods, bio fertilizers and nitrogen levels on growth, yield and economics of wheat 
(Triticum aestivum L.). Ann Agric Res New Series 26: 603-05.

Kachroo, D. and R. Ravinder, 2006. Growth, nutrient uptake and yield uptake as influenced by bio fertilizers and nitrogen. Indian J. Agron., 51: 37-39.

Kakar, K.M., M Arif, S. Ali, 2001. Effect of NP levels, seed rate and row spacing on wheat. Pak J Biol Sci. 4:1319-1322.

Kaur, A., R. K. Pannu, and G.S. Buttar, 2010. Impact of nitrogen application on the performance of wheat (Triticum aestivum) and nitrogen use efficiency under different dates of sowing. Indian J. Agron., 55: 40-45.

Krishnakumari. M., R. K. Sharma, and S. S. Balloli, 2000 Effect of late application of nitrogen on yield and protein content of Wheat. Ann. Agric. Res. 21: 288-91.

Luis López-Bellidoa, Verónica MũnozRomeroa, Jorge Benítez-Vegaa, Purificación Fernández-Garcíaa,Ramón Redondob, Rafael J. López-Bellidoa., 2012. Wheat response to nitrogen splitting applied to a Vertisols in different tillage systems and cropping rotations under typical Mediterranean climatic conditions Europ. J.
Agronomy: 24-32

Sidhu, H. S., 2008 happy seeder-An effort for rice residue management. Indian J. Air. Pol. Con.t 8: 68-75.

Singh, R., and S.K. Agarwal, 2005. Effect of levels on farm yard manure and nitrogen fertilizer on grain yield and use efficiency of nutrients in wheat (Triticum aestivum). Indian J.Agric. Sci., 75: 408-13.

Slattery, M.G., 1998 A study of the balance of tine patterns factors for operating in wheat stubble. In 'International Conference on Engineering in Agriculture'. Perth, W. Aust. p. SEAg.98/044.

Weiner, J., H.W. Griepentrog, L. Kristensen, 2001. Suppression of weeds by spring wheat Triticum aestivum increases with crop density and spatial uniformity. $J$ of Appl. Eco. 38, 784-790.

Wuest, S.B., K.G. Cassman, 1992. Fertilizernitrogen use efficiency of irrigated wheat. 1. Uptake efficiency of preplant versus late season application. Agron. J. $84,682-688$.

\section{How to cite this article:}

Raminder Kaur Hundal, J.S. Kang and Avtar Singh. 2017. Variation in Growth, Yield and Quality of Happy Seeder Sown Wheat with Different Planting Patterns and Times of Nitrogen Application. Int.J.Curr.Microbiol.App.Sci. 6(8): 1420-1428. doi: https://doi.org/10.20546/ijcmas.2017.608.172 